\title{
Stellar Velocimetry with a Novel High Efficiency Interferometer
}

\author{
D.J. Erskine, J. Ge
}

November 3, 2000

U.S. Department of Energy

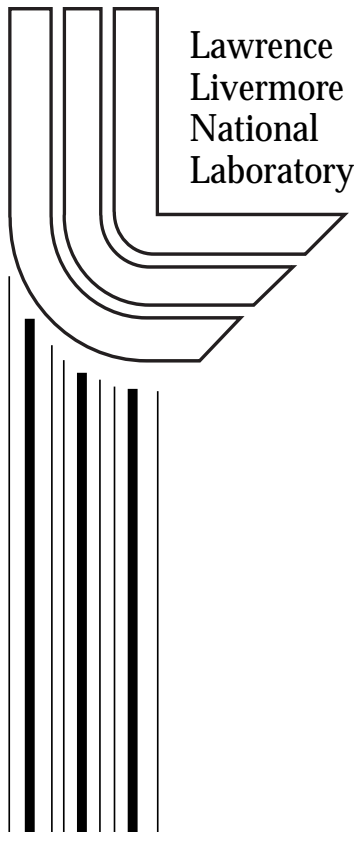




\section{DISCLAIMER}

This document was prepared as an account of work sponsored by an agency of the United States Government. Neither the United States Government nor the University of California nor any of their employees, makes any warranty, express or implied, or assumes any legal liability or responsibility for the accuracy, completeness, or usefulness of any information, apparatus, product, or process disclosed, or represents that its use would not infringe privately owned rights. Reference herein to any specific commercial product, process, or service by trade name, trademark, manufacturer, or otherwise, does not necessarily constitute or imply its endorsement, recommendation, or favoring by the United States Government or the University of California. The views and opinions of authors expressed herein do not necessarily state or reflect those of the United States Government or the University of California, and shall not be used for advertising or product endorsement purposes.

This work was performed under the auspices of the U. S. Department of Energy by the University of California, Lawrence Livermore National Laboratory under Contract No. W-7405-Eng-48.

This report has been reproduced directly from the best available copy.

Available electronically at http://www.doc.gov/bridge

Available for a processing fee to U.S. Department of Energy

And its contractors in paper from

U.S. Department of Energy

Office of Scientific and Technical Information

P.O. Box 62

Oak Ridge, TN 37831-0062

Telephone: (865) 576-8401

Facsimile: (865) 576-5728

E-mail: reports@adonis.osti.gov

Available for the sale to the public from

U.S. Department of Commerce

National Technical Information Service

5285 Port Royal Road

Springfield, VA 22161

Telephone: (800) 553-6847

Facsimile: (703) 605-6900

E-mail: orders@ntis.fedworld.gov

Online ordering: http://www.ntis.gov/ordering.htm

OR

Lawrence Livermore National Laboratory

Technical Information Department's Digital Library

http://www.llnl.gov/tid/Library.html 


\section{Stellar Velocimetry with a Novel High Efficiency Interferometer}

\section{D.J. Erskine \& Jian Ge 98-ERD-054}

The search for extra-solar planets continues to be one of the most exciting fields in astronomy, with great interest shown by the public. The detection of planets via the Doppler effect, measuring the gravitational tugging of the planet on the parent star, is the most popular method. Jupiter and Saturn-like planets create 12 and $3 \mathrm{~m} / \mathrm{s}$ signatures, respectively. Many institutions endeavor to join the search. They are hampered by the lack of affordable instruments having sufficient velocity resolution. Conventional high spectral resolution grating spectrometers are extremely expensive and massive due to their large size (5 meters). Due to their extreme sensitivity to input beam path, the most accurate velocimeters must use the iodine vapor cell as a spectral reference, (which does not deviate the beam due to its absorptive nature.) However, this operates only with green light. Hence, most of the photons from a star are wasted, particularly from red stars. In spite of constituting more than $60 \%$ of stars near Earth, red stars are currently under-represented on planet search surveys due to their relative weakness in the green.

We have developed a new method for measuring Doppler shifts of starlight having many practical benefits. It is based on the combination of an interferometer with a small, low resolution diffraction grating. Since the Doppler effect is measured by fringe shifts, and not directly by the grating, the required grating spectral resolution can be reduced by a factor of 3 to 10 times. Secondly, the tolerance to imperfections in the grating is much higher. These properties allow the overall instrument to be dramatically smaller (TV-sized vs. kitchen sized), inexpensive and portable. Airborne and spaceborne platforms are now possible for the first time. Furthermore, the interferometer is 1000 times less sensitive to errors in the beam path. This enables use of an emission lamp as a spectral reference, which would allow the velocimeter to use all the colors emitted by the star while maintaining high velocity precision. This can increase the flux from red stars by an order of magnitude.

We have conducted proof of principle tests of our instrument prototype on sunlight and bright starlight. Figure A shows that we can dectect the $12 \mathrm{~m} / \mathrm{s}$ amplitude signature of the moon tugging Earth. This is the same amplitude as Jupiter tugging the sun and shows that our velocity resolution and stability is already competitive with conventional instruments, in spite of the lack of refinements of a mature instrument. Figure B demonstrates velocimetry on bright starlight at the Lick 1-meter telescope. This also demonstrates the portability of the instrument, and its relative insensitivity to hostile wind and temperature swings in the observatory dome. Conventional instruments need stringent environmental control to achieve the same velocity resolution.

This was the final year of the LDRD funding. One of the authors (Erskine) was invited by the Univ. of Calif. Berkeley Space Sciences Laboratory to continue the devoloping the instrument through a sabbatical leave. Jian Ge has moved to Penn. State. Univ. and plans to build a similar instrument at the Hobbly-Eberly Telescope.
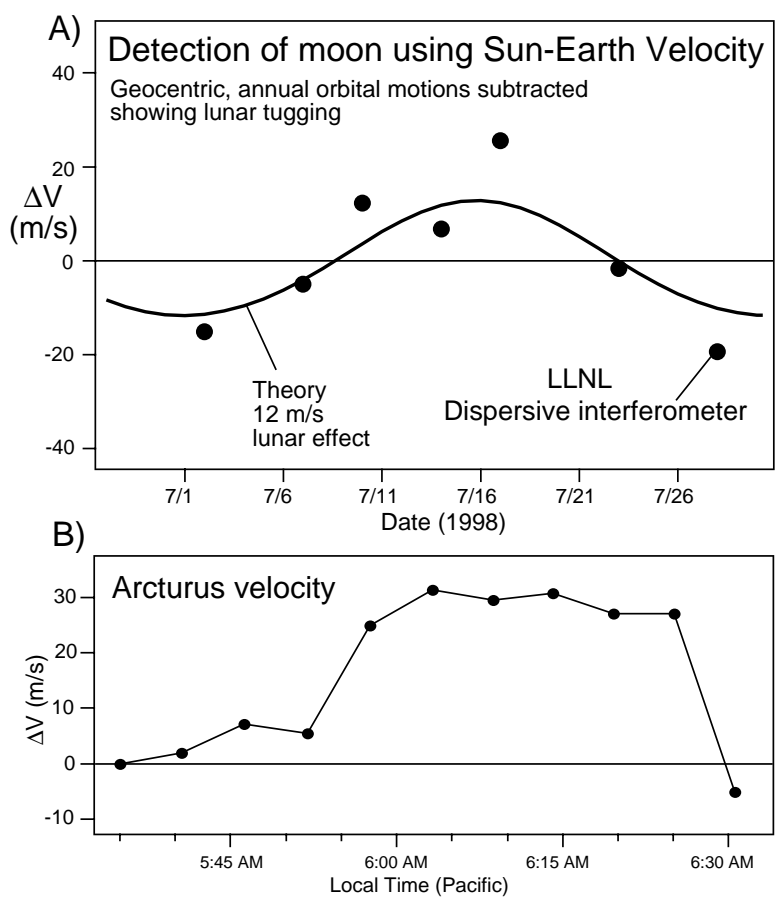

A) Detection of the moon pulling the Earth using our prototype on sunlight. This is the same amplitude as Jupiter pulling the sun, demonstrating that long term stability is sufficiently good to make scientific measurements now. B) Real-time velocity of a bright star (Arcturus) using prototype at Lick 1-meter telescope, showing dynamics of star's photosphere. The grating resolution was 10 times coarser than in conventional instruments, allowing huge savings in cost, size, weight and expense. 